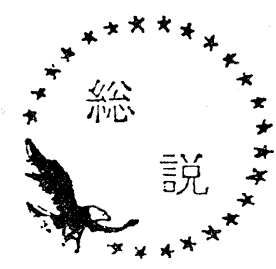

I . まえがき

近年, 都市ガスの需要堌加に呼応して, 石油炭化水 素を原料とする都市ガス製造技術の進歩にはめざまし いものがある。これらのプロセスは原料炭化水素の種 類と発生ガスの性状によつてそれぞれ特徴があるが, 方式的に注触媒使用の有無, 熱授受の方法あるいは連 続式かサイクリック式かによつて分類される。現在, 国内で行なわれているナフサや液化石油ガスのガス化 プロセスとしては, (1)サイクリック式接触改質法, (2) 部分酸化法, (3)連続式高温接触水蒸気改翼法, (4)連続 式低温接触水蒸気改質法がある。

炭化水素を水蒸気と $700 \sim 900^{\circ} \mathrm{C}$ の温度領域で反応せ しめると非常に大きい吸熱を伴い，この吸熱を，(1) 法ではブロ一期にヒート油で，(2) 法では空気あるい は酸素を加えて内熱的に，(3）法では反応管を外熱し て補給している。しかし，反応温度が $550^{\circ} \mathrm{C}$ 程度以下 になると，この反応はいわゆる改質反応のほかにシフ ト反応, メタン化反応あるいは水素化分解反応などが 併発し，吸発熱量がバランスして，ほとんど反応熱 0 の状態でガス化反応を進行せしめることができる。こ れがすなわち（4)の方法であつて，われわれが大阪瓦 斯(株)と共同で開発した MRG プロセスや英国の Gas Council によつて開発された CRG プロセスがこれに 該当する。

本稿では大阪瓦斯(株)北港工場において MRGプロ セスの工業装置が昨年12月稼動したのを機会に，本プ ロセスの開発の経緯やその概要について記述する。

\section{III プロセス開発の経緯}

われわれが天然ガスの接触水蒸気改質反応の研究を 手がけてから10数年になるが，この間わが国における 石油精製工業や石油化学工業の急速な進展に伴い，原 料炭化水素も天然ガスから液化石油ガス，さらにはナ フサへと移行してきた。これらの動向に応じて研究対 象も高級炭化水素へと移行してきたが，天然ガスすな わちメタンの水蒸気改質反応と違つて高級炭化水素の
それでは炭素一炭素結合の開裂が起こり，反応条件や 触媒特性によつて発生ガスの性状や炭素質の析出状況 が異なることに注目し，低温域の反応の研究圭開始し た。

またここの種の反忘においてイオウが触架瑇である ことは周知のことであり, 反応温度が低くなればその 影響はさらに大きくなる。一般に Co-Mo 系あるいは Ni-Mo 系の脱硫触媒では脱硫用水素中の一酸化炭素 と炭酸ガスの濃度をある限界以下にする必要がある。 したがつて，一酸化炭素や炭酸ガスを相当量含有する 都市ガスなどをとのまま水素化脱硫用水素源として使 用できる脱硫法の研究をも同時に行なつた。

研究開発の段階はつぎのとおりである。

(1) 化学平衡論的検討

ガス化反忘の研究において化学平衡論的検討はとく に重要である。すなわち, 通常のガス化反応は化学平 衡論の示す結果どおりに完結し, 反応上触媒の選択性 などが大きく寄与することがないからである。時あた かも電子計算機の実用化段階に入つており, 電子計算 機を用いて広範に平衡論的検討を行なつた。

(2) ミゼットプラント(等温反応器)による研究

本反応は徒来の水蒸気改質反応にくらべ反応温度が 著しく低いため, 非常に活性の高い触媒が要求され る。そこで, 数基のミゼットプラントを用いて反応特 性の解明と触媒の改良を重㸚, さらに工業化に要する 反応工学的資料を採取した。

(3) ミゼットプラント(断熱反応器)による研究

基礎研究の結果を基に触媒量 $5 l$ と $30 l$ の断熱反応装 置を設計し実験検討した結果，基礎実験からの計算結 果とよく符合し，スケールアップの可能性が実証され た。

\section{(4) パイロットプラントによる研究}

上記の基礎実験に基づき，大阪瓦斯(株)の協力を得 て同社総合研究所内に $15,000 \mathrm{Nm}^{3} /$ 日 $\left(6,000 \mathrm{kcal} / \mathrm{Nm}^{3}\right.$ 基準) のパイロットプラントを建設し，両社緊密な協 
力のもとに共同研究を実施した。昭和39年11月より翌 年 4 月まではイオウを含まないエデックス・ラフイネ 一トを原料として 3 回の連続運転を行ない，その後脱 硫装置を附設し, 同年 8 月より 12 月までライトナフサ を原料として長期連続運転を実施し, 触媒性能, 装置 の運転性, 運転方法などについて充分の知見を深め, 工業化のみとおしを得ることができた。脱硫装置附設 前の運䎐結果はすでに報告1)されているので参照願い たい。

このパイロットプラントの成果を基礎にさらに触媒 の改良を行ない，装置設計の基礎資料も整い，経済的 検討も完了して昭和41年12月大阪瓦斯(株)北港工場に $200,000 \mathrm{Nm}^{3} /$ 日 $\left(4,500 \mathrm{kcal} / \mathrm{Nm}^{3}\right.$ 基準)の大型装置が建 設された。この装置は昨年12月運転開始してから本年 4月末まで順謂に䄇動し，パイロットブラントの結果 から予期した以上の好成績齐拉的ている。

\section{III. 基礎反応}

本プロセスの基礎反応としては原料炭化水素中のイ オウ化合物の水素化脱硫反忘上脱硫精製された炭化水 素の水蒸気改質反応とがある。

\section{1. 水素化脱硫反店}

原料炭化水素中のイオウ化合物はも之の原油の種類 とその留分によつて異なるが，ナフサの場合主として 硫化水素, メルカプタン類, サルファイド類, ダイサ ルフアイド類, チオフエン類などがある。これらのイ オウ化合物はそれぞれ次式のように水素化分解されて 炭化水素上硫化水素になる。

$$
\begin{aligned}
& \mathrm{RSH}+\mathrm{H}_{2} \longrightarrow \mathrm{RH}+\mathrm{H}_{2} \mathrm{~S} \\
& \mathrm{RSR}^{\prime}+2 \mathrm{H}_{2} \longrightarrow \mathrm{RH}+\mathrm{R}^{\prime} \mathrm{H}+\mathrm{H}_{2} \mathrm{~S} \\
& \mathrm{RSSR}^{\prime}+3 \mathrm{H}_{2} \longrightarrow \mathrm{RH}+\mathrm{R}^{\prime} \mathrm{H}+2 \mathrm{H}_{2} \mathrm{~S} \\
& \mathrm{I}^{+\mathrm{R}}+4 \mathrm{H}_{2} \longrightarrow \mathrm{RC}_{4} \mathrm{H}_{9}+\mathrm{H}_{2} \mathrm{~S}
\end{aligned}
$$

これらの反応は発熱反応であり, 平衡論的には低温 程有利であるが，反応速度の点から一般に $350 \sim 400^{\circ} \mathrm{C}$ の温度域で行なわれる。しかし，この温度域でも通常 の圧力, 水素使用量の条件下では平衡論的に反応はほ とんど不可逆的に進行する。

水素化用水素ガス中に炭酸ガスや一酸化炭素がある 之, 常用される Co-Mo 系触媒の場合次式に示寸副反 応が併発する。

$$
\begin{aligned}
& \mathrm{CO}_{2}+4 \mathrm{H}_{2} \rightleftarrows \mathrm{CH}_{4}+2 \mathrm{H}_{2} \mathrm{O} \\
& \mathrm{CO}+3 \mathrm{H}_{2} \rightleftarrows \mathrm{CH}_{4}+\mathrm{H}_{2} \mathrm{O} \\
& \mathrm{CO}+\mathrm{H}_{2} \mathrm{~S} \rightleftarrows \mathrm{COS}+\mathrm{H}_{2}
\end{aligned}
$$

（5）（6）式の反応は非常に大きい発熱反応であり, 反応温度を上昇せしめ, また水素分圧を減少せしめる
ため好ましくない。(7) 式の反応によつ下チオカルボ ニルが生成すると硫化水素吸着剤の吸着性能を低下せ しめる。したがつて，Co-Mo 系触媒では走素中の一 酸化炭素と炭酸ガスの量を規制する必要がある。これ に対し当社が日揮化学(株)と共同で開発した水素化脱 硫触媒はきわ加て選択性が高く, 本プロセスの生成ガ スである $\mathrm{H}_{2} 24 \%$ ，( $\left.\mathrm{CO}+\mathrm{CO}_{2}\right) 23 \%$ 程度のガスを使 用しても上記の副反応を全く起こさず，脱疏反忘が選 択的に起こり，生成ガスるそのまま水素化用水素とし て使用しうる点が大きい特色となつている。

ライトラフサの場合, 上記のような低水素濃度の水 素化用ガスを $0.3 \mathrm{~mol} / \mathrm{mol}$ 炭化水素, 圧力 $10 \mathrm{~kg} / \mathrm{cm}^{2} \cdot \mathrm{G}$, 温度 $350^{\circ} \mathrm{C}$ で反応に供して数 p. p. m. まで充分脱硫で きる。

2 . 水蒸気改質反応

炭化水素と水蒸気の接触改質反応の反忘機構の詳細 は明らかでないが，一般に総括反応式としてつぎの 3

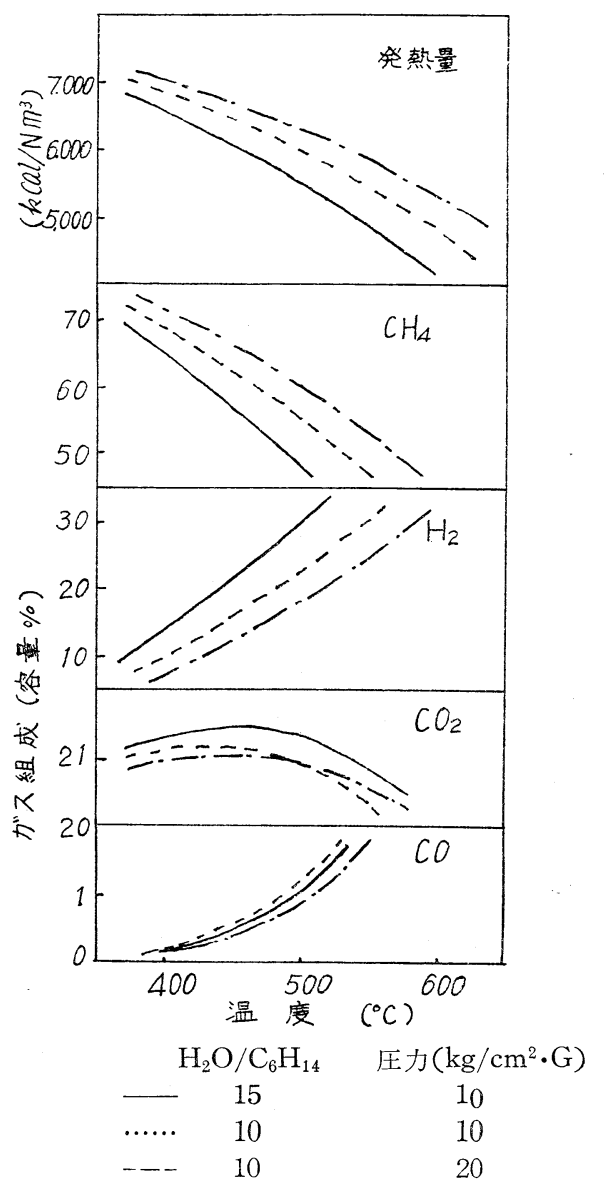

図 1 n- $\mathbf{C}_{6} \mathbf{H}_{14}-\mathbf{H}_{2}$ O反応の平衡組成 
式で表わされる。

$$
\begin{aligned}
\mathrm{C}_{m} \mathrm{H}_{n}+m \mathrm{H}_{2} \mathrm{O} \rightleftarrows m \mathrm{CO}+(m+n / 2) \mathrm{H}_{2}- \\
\mathrm{CO}+3 \mathrm{H}_{2} \rightleftarrows \mathrm{CH}_{4}+\mathrm{H}_{2} \mathrm{O} \\
\mathrm{CO}+\mathrm{H}_{2} \mathrm{O} \rightleftarrows \mathrm{CO}_{2}+\mathrm{H}_{2}
\end{aligned}
$$

$600^{\circ} \mathrm{C}$ 程度以下の低温域においても，触媒の活性が 充分であれば，炭化水素は（8)式によつて分解し反応 生成物の間には（6)，(9) 式の平衡がなり立つ。(8) 式は大きい吸熱反応であり（6)，(9) 式は発熱反応で あつて，また（6)式はモル数減少の反忘である。そこ で反応温度が下がり，圧力が高くなるほど（6)，(9)式 は右へずれ，反応全体として発熱側へ移行する。逆に 温度が上がり圧力が低下すると吸熱側一移行し，適当 な条件を選べば反応熱 0 で反応が進行する。( 8$)$ 式の 物質收支と（6)，（9）式の平衡関係からノルマル・へ キサンー水蒸気反応の平衡組成を計算した結果を図1に 示す。この図から温度, 圧力, 水蒸気比の生成ガス組 成や発熱量におよぼす影響は明らかである。

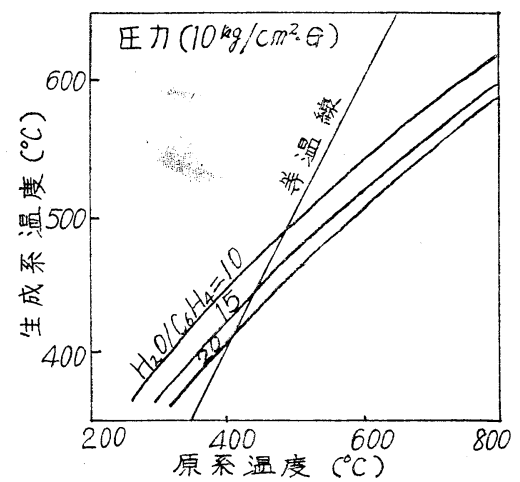

図 $2 \mathbf{n}-\mathbf{C}_{6} \mathbf{H}_{14}-\mathbf{H}_{2} \mathbf{O}$ 断熱反応における 原系温度と生成系温度の関係

図 2 は圧力 $10 \mathrm{~kg} / \mathrm{cm}^{2}$ ・Gでノルマル・ヘキサンと水 蒸気を断熱的に反応せしぬた場合の原系と生成系の温 度関係を表わしたものである。水蒸気比をパラメータ とした各線が図中の等温線と交差する点がすなわら反 応熱 0 であり，等温線より下部は吸熱側であり上部は 発熱側といらことになる。圧力が同じであれば水蒸気 比が大きい程吸熱側へ移行することがわかる。

図 3 はノルマル・ヘキサンと水蒸気の反応において 反応熱 0 の条件を図示したものであるが, 圧力も $20 \mathrm{~kg}$ $/ \mathrm{cm}^{2} \cdot \mathrm{G}$ を越すと反応熱に大きく影響しなくなること がわかる。

高級炭化水素の水蒸気改質反応においては触媒上に 炭素の析出を起こさないことが重要な問題である。炭

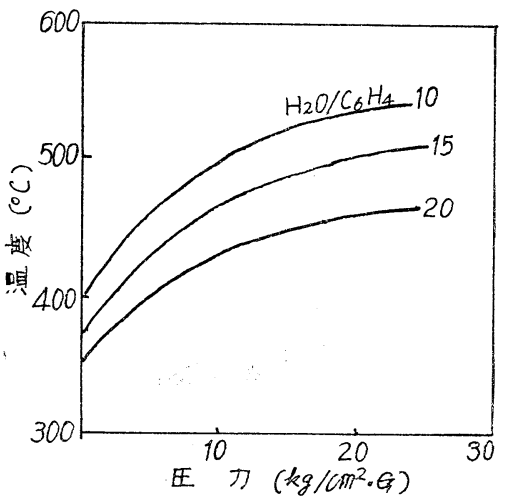

図 $3 \quad \mathrm{n}-\mathrm{C}_{6} \mathbf{H}_{14}-\mathrm{H}_{2} \mathrm{O}$ 断熱反応に おける等温線

素の析出を化学平衡論的に考察するにはつぎの(10)あ るいは(11)式で示される一酸化炭素またはメタンの分 解平衡を考えればよい。

$$
\begin{aligned}
2 \mathrm{CO} & \leftrightarrows \mathrm{CO}_{2}+\mathrm{C} \\
\mathrm{CH}_{4} & \longleftrightarrow \mathrm{H}_{2}+\mathrm{C}
\end{aligned}
$$

(10)，(11)式の平衡定数をそれぞれ $\mathrm{K}_{1} ， \mathrm{~K}_{2}$ とし (8)，(6)，(9) 式から計算される平衡組成における炭 酸ガス，一酸化炭素，水素，メタンの活量をそれぞれ $a_{\mathrm{CO}_{2}}, a_{\mathrm{CO}}, a_{\mathrm{H}_{2}}, a_{\mathrm{CH}_{4}}$ とすると，炭素が析出しな いためには,

$a_{\mathrm{CO}_{2}} / a_{\mathrm{CO}^{2}}>\mathrm{K}_{1}$ あるいは $a_{\mathrm{H}_{2}}{ }^{2} / a_{\mathrm{CH}_{4}}>\mathrm{K}_{2}$ が満足されればよい。上法によつて計算したノルマル ・ヘキサンと水蒸気の反応の炭素析出限界を図 4 に示 した。しかし，この計算は反応が平衡に到達した状態

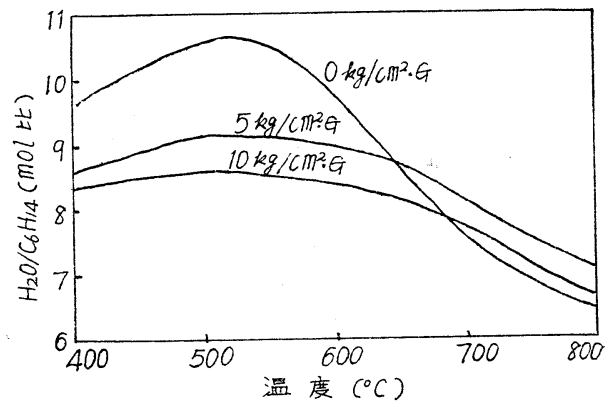

図 $4 \quad \mathbf{n}-\mathrm{C}_{6} \mathrm{H}_{14}-\mathrm{H}_{2}$ O反応の炭素析出限界線

での議論であり，実際には反応途中において炭化水素 の分解重合からくる炭素質の析出を考慮しなければな らない。したがつて，平衡論的考察からえられる水蒸 気比は最低水蒸気比であり，実際的には触媒の特性や 反応条件，原料性状などによつて後者の炭素質の析出 を防止するため余剩の水蒸気を使用している。 
以上の諸点を考慮すると，与えられた原林から断熱 的に反応を行なわせ所望のガスを得る反応条件は容易 に決定される。

実験室の断熱型ミゼットプラントで行なつたガス化 触媒層の軸方向温度分布の数例を図 5 亿示す。曲線 1

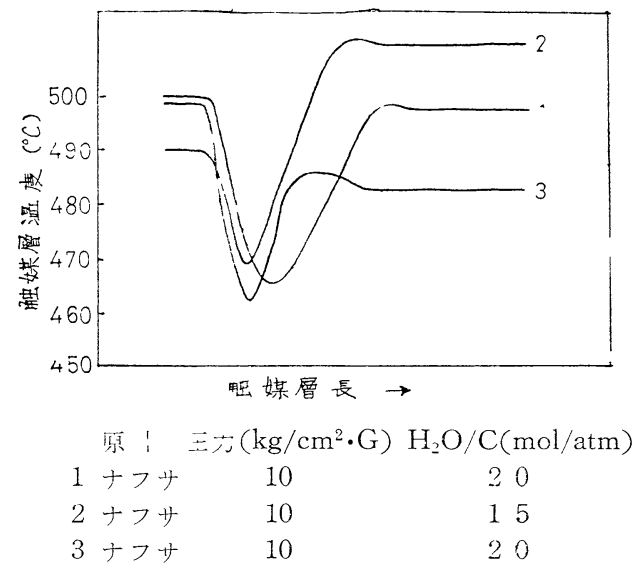

図 5 ガス化触媒層の温度分布

2, 3 をみると反応の初期段階てはます炭化水素と水蒸 気の反応が優先し，この吸熱のために触媒層の温度は 低下するが，反応の進行につれ水素濃度が高くなると メタン化反応が優勢になり，この発熱のため触媒層の 温度は上昇しはじめ, 反応が完結し平衡に達すると一 定温度すなわち平衡温度を示すようになる。触媒が劣 化するにつれ，この温度分布は時間の経過とともに触 媒層の出口別に移行するが, 触媒層に温度分布の平担 部かあるかきり生成ガス組成は変わらす未分解原籵も 検知されない。また, 温度分布の形は原籵が同一であ つても反応条件が異なると変化し, 反応条件か同一で あつても原料が異なると変化することかこの凶によく みられる。因 2 に示したように触媒層人口, 昷度と平衡 温度の関係は反応温度, 圧刀, 水蒸気比なとの反応条 件かきまれは平衡計算とこれに基つく熱計算から算出 できるわ沙てある。

このように本反応は化学平衡論的に反応結果か正確 に予想でき，しかも簡单なトラム型断熱反応器てほと んと反応熱 0 の状態で反応を行ならことかてきるので 反応器の設訃はきわめて容易である。しふし, 触媒と しては従来の高温改質反応にくらへ相当に低い温度で 使用するため高活性が要求され, 同時に炭素の析出も 防止しなけれはならない。また， $500^{\circ} \mathrm{C}$ 前後の温度と はいえ反応に対する抬散の影響位相当に大きいのて, 触媒としては内部拡散抵抗を小さくすることが重要で
あり，反応器設計時には流速の選定に注意を要する。

触媒の充塡量は前記の触媒層温度分布の移動速度す なわち触媒寿命を考慮して, 所望運転期間未分解炭化 水素が出ないようにきめれはよい。

原林炭化水亲としてはフタンやナフ业留分ふとか使 用されるが, 軽質のものほと反応速度孔速く, 触媒寿 命も長い。また，原林中のイオウ化合物や酸素はある 限界以下までは除去しなけれはならす, 芳香族やオレ フイン頻も触媒寿命に悪影響をおよほすため, 多量に 混入するのは好ましくない。

\section{IV プロセスの概要と運転成績}

昨年12月大阪瓦斯(株)北港工場において稼動した装 置の概要と運転成績について述へる。

\section{1 プロセスの概要}

本装置は比重 $0 € 8$ 程度, イオウ含有量 $260 \mathrm{p} \mathrm{p} \mathrm{m}$ 程度の十フサを原林とし, 水蒸気比 2 , ガス化温度 $500^{\circ} \mathrm{C}$, 生成カスのブラント出口压力 $10 \mathrm{~kg} / \mathrm{cm}^{2} \cdot \mathrm{G} \tau$ ガス製造能力 $200,000 \mathrm{Nm}^{3} /$ 日 $\left(4,500 \mathrm{kcal} / \mathrm{Nm}^{3}\right.$ 基榫) の設計になつている。然林は重油を使用し, 廃熱の回 収によつて低圧蒸気を発生するようになつているが, プロセス用水蒸気は单独ホイラーから供給される。

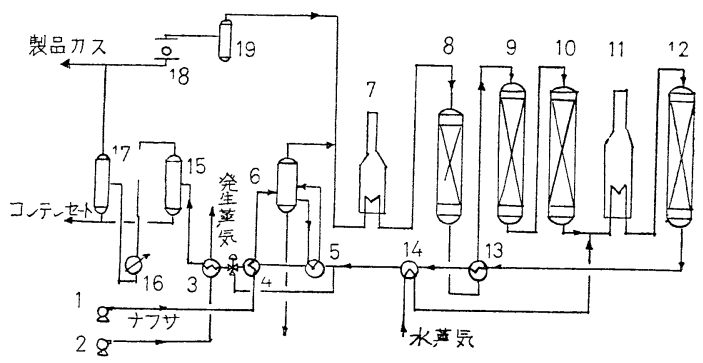

1 原朴ポンプ 2 給水ポンプ 3 冷 却 器 4 ナフサ予熱器 5 ナフ歯発器 6 ナフサ気液分離器 7 加 熱 炉 8 水素化脱硫器 9 吸着脱硫器 10 吸着脱硫器 11 加 熱 炉 12 力又化反応器 13予 熱 器 14 水蒸気過熱器 15 トレーン分離器 16冷却器 17 トレーン分離器 18 循環カス圧縮器 19 ソンクアウトトラム

\section{図 6 JGC式MRGプロセス作業系統図}

6 図に示した作業系統図についてプロセスの概要を 説明する。原料ナフサ製造ガスとの熱交換により予 熱され, さらにナフサ祭発器によつて気化されて気液 分離器を出た後流量制御され, 循環ガス圧縮機よりの 流量制御された水素化脱硫用ガス（製造ガスの一部）

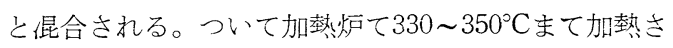
れ, 水素化脱硫器てナフサ中の有機イオウは硫化水素 
に変換される。脱硫されたナフサと硫化水素はさらに 製造ガスとの熱交換により $380 \sim 400^{\circ} \mathrm{C}$ に加熱されて吸 着脱硫器に入り硫化水素を吸着除去する。脱硫精製さ れたナフサは水蒸気過熱器で製造ガスによつて過熱さ れた水蒸気と混合し，加熱沪でガス化に必要な温度 $480 \sim 500^{\circ} \mathrm{C}$ まで加熱され，ガス化反応器に入りガス化 される。ガス化反応器を出た製造ガスは, 前述のよう に吸着脱硫器入りのナフサ, プロセス水蒸気, 原料ナ フサと順次熱交換し，さらに低圧蒸気を発生して熱回 収され, 最終冷却器で常温まで泠却された後ドレーン を分離して $10 \mathrm{~kg} / \mathrm{cm}^{2} \cdot \mathrm{G}$ でプラントを出る。その一部 は水素化用ガスとして循環される。

流量, 生力, 温度, 液面調節などの運転上の制御は 充分行なわれているが，ナフサと水蒸気，臌環ガスと 水蒸気には比率制御を行ない，緊急時のトリップ回路 を設けて触媒や装置の保護には万全を期している。卜 リップ回路としては制御空気圧，ナフサポンプ，（停 止), 水蒸気比, 加熱炉の出口温度をとつて抢り, こ れらが設定值をずれると緊急遮断弁が作動して装置は 自動的に停止する。このように本装置は非常に簡単で 運転も容易であり，運転員も少なくてよい。

本装置に使用した触媒はつぎのと预りである。

ガス化触媒 N182 (日揮化学製)

水素化脱硫触媒N116(日揮化学製)

吸着脱硫触媒ICI-32-4(ICI製) 3/4 量 N741（日揮化学製） $\quad 1 / 4$ 量

2. 運転成績

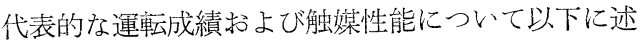
ベる。

（1）原料性状の 1 例

$\begin{array}{lc}\text { 比重 }\left(15 / 4^{\circ}\right) & 0.678 \\ \text { 蒸留性状 } & \\ \text { IBP } & 37.1^{\circ} \mathrm{C} \\ 10 \% & 50.4 \\ 50 \% & 70.0 \\ 90 \% & 104.5 \\ \mathrm{EP} & 132.3 \\ \mathrm{PONA}(\text { 容量\%) } & \\ \text { パラフイン } & 84.8 \\ \text { オレフイン } & 0.2 \\ \text { ナフテン } & 12.4 \\ \text { 芳 香 族 } & 2.8 \\ \text { 元素分析(重量\%) } & \\ \text { 炭素 } & 84.13 \\ \text { 水素 } & 15.87\end{array}$

平均分子量 84.4

イオウ(p.p.m.) 105

（2）操作条件の変動範围

1)原料ナフ市

$2,400 \sim 4,800 \mathrm{l} / \mathrm{hr}$

2)水蒸気/炭素

3)循環ガス/ナフサ

$1.5 \sim 2.0 \mathrm{~mol} /$ atom

$0.31 \mathrm{~mol} / \mathrm{mol}$

4)各部の条件

ガス化触媒入口温度

ガス化触媒出口温度

$475 \sim 500^{\circ} \mathrm{C}$

水素化脱硫触媒温度

$485 \sim 500^{\circ} \mathrm{C}$

$347 \sim 355^{\circ} \mathrm{C}$

吸着脱硫触媒温度

$381 \sim 392^{\circ} \mathrm{C}$

ガス化触媒出口圧力

$10.5 \sim 11 \mathrm{~kg} / \mathrm{cm}^{2} \cdot \mathrm{G}$

系内出口圧力

$9.7 \sim 10.2 \mathrm{~kg} / \mathrm{cm}^{2} \cdot \mathrm{G}$

（3）運転結果の代表例

1)製造ガス性状

(平衡計算值)

$\begin{array}{lcc}\mathrm{CH}_{4} & 54.1 \text { vol\% } & 53.71 \text { vol\% } \\ \mathrm{CO} & 0.8 & 0.96 \\ \mathrm{CO}_{2} & 21.6 & 21.82 \\ \mathrm{H}_{2} & 23.5 & 23.51\end{array}$

総発熱量

$\mathrm{kcal} / \mathrm{Nm}^{3} \quad 5,897 \quad 5,849 \quad 5,861$

$\begin{array}{lll}\text { 比重 } & 0.652 & 0.653\end{array}$

（ユンカース実測值）

2）方ス化成績

$\begin{array}{lrl}\text { 産気量 } & 1,399 & \mathrm{Nm}^{3} / \mathrm{k} l \\ \text { 得 } & 820 & \mathrm{JHU} / \mathrm{k} l\end{array}$

3）物質収支

炭素収支 $\quad 100.6 \%$

水素收支 $\quad 101.9 \%$

4）熱効率 $93 \%$ (回収水蒸気を含屯）

前述したように，以上の結果をみると製造ガス性状 は平衡計算值と誤差範囲内においてよく一致すること がわかる。

また，すべての触媒が予期以上の性能を示した。 1 80p.p.mのイオウを含む原料ナフサの水菜化脱硫器出 口のイオウ含有量は 1.7 p. p. m. であり吸着脱硫器出口 では0.5p.p.m.であつた。(ウイックボールド法分析に よる)

吸着脱硫器の上層部に充垻したN741 (ZnO) の硫化 水素吸着量を測定した結果25重量\%(吸着済重量基準) 以上の吸着量があり従来の酸化亜鉛触媒よりかなり高 性能であることが判明した。ガス化触媒についても， 途中低水蒸気比運転や負荷変動なども行なわれたが, 設計条件どうりの運転を継続した場合には 1 年以上の 寿命があるものと考えられる。負荷変動も非常に簡単 
にしかも短時間に行ならことができ，触媒にも何ら悪 影響注なかっ。

\section{V. プロセスの特徵}

これまでの記述から容易にわかるように，このプロ セスにはつぎのような特徴がある。

1）熱効率が高い。

2）装置が簡単で運転も容易である。

3）建設費がやすい。

4）負荷変動が容易である。

5）製造ガスが無毒性である。

6）運転条件を変化せしめて容易に所望ガスをうる ことができる。

また，MRG プロセスにおいては水素化脱硫用水素 の精製を行なら必要がなく，生成ガスをそのまま使用 できる点に大きい特色を有している。さらに，生成方 スの脱炭酸あるいはメタネーション反応などを行なう
ことによりナフサやブタンなどから高呩度のメタンを 製造することさできる。

\section{VI.むすび}

本稿で法宸化水菜の低温水蒸気改筫法についてJGC 式MRGプロセスを中心に記述した。われわれは現在， よりよい触媒の開発とプロセスの改良遥歩に努力を続 けているが，近い将来汇はもつ上重貿の原料までも使 用可能にしたいと考えており，またその閏能性を見出 しつつある。このような本プロセスの改良や進歩てつ いては将来機会をみて発表したいと考えている。

最後に, 終始本プロセスの開発に御掊力い灾だいた 大阪瓦斯株式会社および日揮化学棕式会社の関係者の 方々に深甚なる謝意を玟する。

\section{文 献}

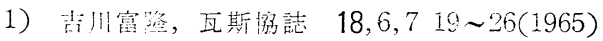

\title{
Low Temperature Steam Refoming Process of Petroleum Hydrocarbons
}

_JGC MRG (Methane Rich Gas) Process-

by Shohachi Egashira

(Japan Gasoline Co., Ltd. )

\begin{abstract}
SYNOPSIS:-Recently in the gas industry, a great progress has been made in the gasification technique of petroleum hydrocarbons. Especially, the gasification process of light petroleum distillate by low temperature catalytic steam reforming under pressure has been recieving world wide attention as an economical process for the production of high calorific gas last few years.

This paper describes the progress of the development research, fundamental reactions, the outline of the JGC MRG process and the operation data obtained by the commercialized plant.
\end{abstract}

